\title{
DETERMINATION OF SPORT PARTICIPATION MOTIVATION OF YOUNG ATHLETES FROM DIFFERENT COMBAT SPORTS ${ }^{1}$
}

\section{FARKLI MÜCADELE SPORLARINDAKI SPORCULARIN SPORA KATILIM GÜDÜLERINIIN BELİRLENMESI}

\author{
Hakan KOLAYIŞSi, İhsan SARI ${ }^{2}$, Nurullah ÇELIK ${ }^{3}$ \\ ${ }^{1-2-3}$ Sakarya University, Faculty of Sport Science, Sakarya / Turkey
}

ORCID ID: 0000-0001-9448-1463', 0000-0002-9090-84472, 0000-0003-0220-5344

Öz: Amaç: Bu araştırmanın amac1 12-16 yaş grubundaki sporcuların spor türüne göre spor katılım motivasyonunun belirlenmesidir. Yöntem: Araştırmaya 409'u erkek (\% 67.7) ve 195 'i kadın (\% 32,3) olmak üzere toplam 604 sporcu gönüllü olarak katılmıştır. Sporcular Spora Katılım Güdüsü Ölçeği'ni doldurmuşlardır. Veriler betimsel istatistikler ve MANOVA ile analiz edildi. Post hoc analizi olarak Tukey testi kullanılmıştır.. Anlamlılık düzeyi 0,05 olarak belirlenmiştir. Bulgular: Sonuçlara göre sporcuların spor katılım motivasyonunun spor türüne göre farklılaştığı görülmüştür. F (40, $2578.00)=3.425, \mathrm{p}=.000 ;$ Wilks' $\lambda=.798 ;$ Kısmi $\eta 2$ $=.044$. Her bir bağımlı değişken için sonuçların analizi, spor türü bakımından takım bağlılığı $\mathrm{F}(5,598)=$ $10.742, \mathrm{p}=.000, \mathrm{k} 1 \mathrm{smi} \eta 2=.082 ;$ fitnes $/$ enerji salımı $\mathrm{F}(5,598)=4.204, \mathrm{p}=.001$, k1smi $\eta 2=.034$; haz duyma $\mathrm{F}(5,598)=3.855, \mathrm{p}=.002$, k1smi $\eta 2=.31$; arkadaşlık $\mathrm{F}(5,598)=2.567, \mathrm{p}=.026$, kısmi $\eta 2=.021$; ve yarışma boyutu $F(5,598)=4.040, p=.001$, kısmi $\eta 2=.033$. arasında anlamlı farklar ortaya koymuştur. Sonuç: Bu araştırmanın sonuçları farklı dövüş sporlarından ile ilgilenen genç sporcuların güdülenme özelliklerini ortaya koymaktadır.

Anahtar Kelimeler: Dövüş Sporları, Güdülenme, Spora Katılım, Sporcu
Abstract: Aim: The aim of this research was to determine the sports participation motivation of athletes aged 12-16 according to sports type. Method: 409 male $(67.7 \%)$ and 195 female $(32.3 \%)$ athletes, as a total of 604 athletes voluntarily participated in the research. Athletes completed a Participation Motivation Questionnaire (Gill, Gross, \& Huddleston, 1983). The data were analysed by descriptive statistics and MANOVA. Tukey was used as a post hoc analysis. Level of significance was determined to be 0.05 . Results: According to the results, it was seen that sport participation motivation of the athletes differs according to sport type $F$ $(40,2578.00)=3.425, \mathrm{p}=.000$; Wilks' $\lambda=.798$; Partial $\eta 2=.044$. Analysing the results for each dependent variable showed that there was a significant difference in team affiliation $\mathrm{F}(5,598)=10.742, \mathrm{p}=.000$, Partial $\eta 2=.082 ;$ fitness/energy release $\mathrm{F}(5,598)=4.204, \mathrm{p}=$ .001 , Partial $\eta 2=.034$; enjoyment $F(5,598)=3.855$, p $=.002$, Partial $\eta 2=.031$; friendship $F(5,598)=2.567$, $\mathrm{p}=.026$, Partial $\eta 2=.021$; and competition $\mathrm{F}(5,598)$ $=4.040, p=.001$, Partial $\eta 2=.033$ according to sport type. Conclusion: The results of this research reveal the motivational features of young athletes from different combat sports.

Key Words: Combat Sports, Motivation, Sport Participation, Athlete

Doi: $10.17363 /$ SSTB.2018.2.2

(1) Sorumlu Yazar: Hakan KOLAYIŞ, Sakarya Universitesi, Faculty of Sport Sciences, Esentepe Campus, Sakarya / Turkey,hkolayis@sakarya.edu.tr, Geliş Tarihi / Received: 21.02.2018, Kabul Tarihi / Accepted: 19.06.2018, Makalenin Türü: Type of article (Araştırma - Uygulama / Research -Application) Çıkar Çatışması / Conflict of Interest: Yok / None Etik Kurul Raporu/Ethics Committee: Yok / None 
International Refereed Academic Journal of Sports, Health and Medical Sciences April - May - June Issue: 27 Spring Summer Year: 2018

Uluslararası Hakemli Akademik Spor Sağlık ve Tıp Bilimleri Dergisi

Nisan - Mayıs - Haziran Sayı: 27 İlkbahar Yaz Dönemi Yıl: 2018 ID:380 K:402

ISSN Print: 2146-8508 Online 2147-1711

(ISO 18001-OH-0090-13001706 / ISO 14001-EM-0090-13001706 / ISO 9001-QM-0090-13001706 / ISO 10002-CM-0090-13001706) (TRADEMARK)

(2015/04315- 2015-GE-18972)

\section{INTRODUCTION}

Koivula (1999:361) indicates benefits of regular exercise in both physical and psychological aspects, adding that regular participation in sport activities ensures improvement in physical and mental health, decrease in mental stress and anxiety, as well as vigour and open-mindedness. In the light of such positive influences, it is important for creation of a healthier society to determine why individuals participate in regular exercise and sport, as well as the motive behind such behaviour. As for performance sports, determination of reasons behind preference of sport by individuals may unearth applications directed at performance improving. Sport psychology intends to explain behaviours in sports environment and to bring along various approaches in this respect; indeed, it is capable of explaining, by several theories, the motives for individual tendency to sports. In this context, the self-determination theory by Deci and Ryan (1985) indicates that human behaviour is based on three fundamental psychological requirements, namely, autonomy, competence and relatedness (Frederick and Schuster, 2003:241). Accordingly, as Ryan and Deci (2000:54) remark, the theory can distinguish various types of motivation based on various reasons and objectives that lead to action, adding that the most important basic distinction is between "intrinsic motivation," which means to do something because of its interesting or entertaining character by nature, and "extrinsic motivation," which means to do something for an external acquisition (Ryan and Deci, 2000:55). According to Cognitive Evaluation Theory, a sub-theory of self-determination, Deci et al., (1975:82) state that a behaviour guided by intrinsic motivation renders one self-sufficient and capable of making his own decisions; besides, when one is intrinsically motivated, he has himself as focus of causality. On the other hand, external prizes or feedbacks may trigger feeling of competence and decision-making, and thus they may influence intrinsic motivation.

As for sports environment, it is well known that there are many factors influential on participation, continuity and performance. Fun, health, status and performance are among notable concepts regarding individual tendency for sports. On the other hand, motivation is an important factor with respect to continuity and achievement parameters in sports, as well as orientation to it (Altıntaş and Koruç, 2014:62). Cognitive evaluation theory lays stress on intrinsic motivation; accordingly, individuals who participate in activities freely without any external pressure can fulfil their requirement of autonomy and improve their skill and self-confidence to a certain extent. Consequently, it paves the way for increasing competence and self decision-making, which 


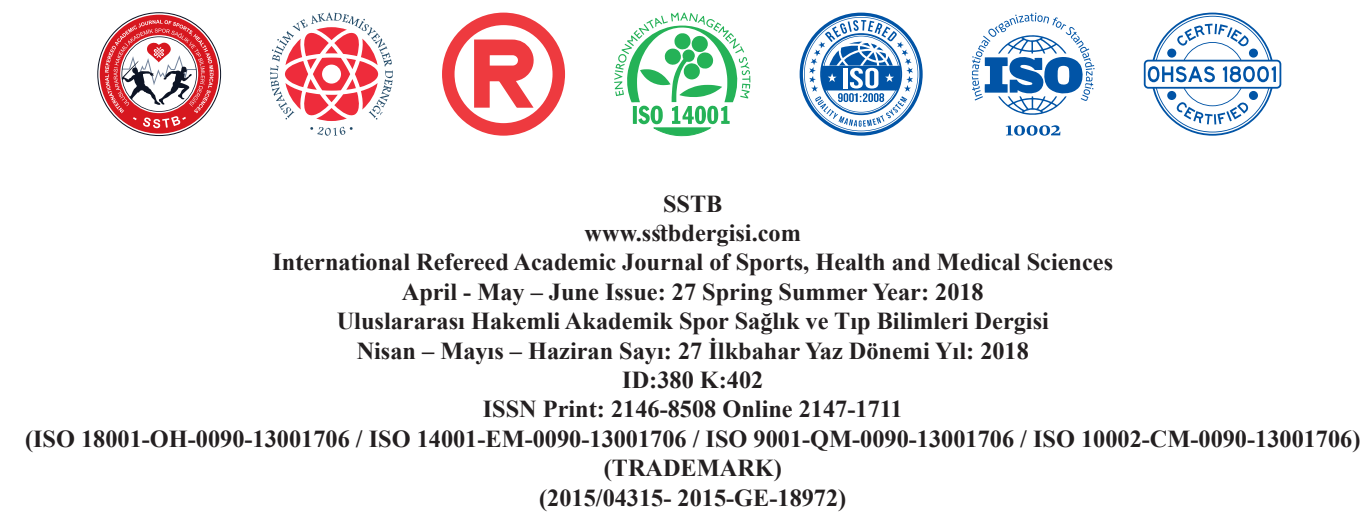

in turn leads to appearance of intrinsic motivation, whereupon the individual participates in sports (Frederick and Schuster, 2003:240). An analysis on relevant literature manifests more positive results of activities due to intrinsic motives (Ingledew, Markland, \& Medley, 1998; Afzal, Imran, Aslam \& Kashif, 2010; Moreno, González-Cutre, Martín-Albo, \& Cervelló, 2010).

The literature reveals that sport psychologists have notably dwelled on determination of elements that lead youngsters to participate in competitive sports. In addition to psychological factors about youth participation in sports, the reasons for continuing or giving up sports have been popular subjects regarding participation (Weinberg et. al., 2000:323). As a matter of fact, Clews \& Gross (1995:90) Morris, Clayton, Power, \& Jin-Song (1996:364), Weiss \& Chaumeton (1992:61) analysed youth participation in competitive sports, while Rintaugu \& Nteere (2011) asserted that college athletes begin sports due to need of mastering in competitive environment. Gill, Gross \& Huddleston (1983:1), Kolt et al (1999:381), White \& Duda (1994:4) carried out studies, according to which the reasons for participation in sports include skill development and learning, fun, fitness, making friends and achievement. According to Visek et al., (2015) Children cite 'fun' as the primary reason for participation in organized sport.
Relevant studies put forth various motives to encourage children to participation in sports. Besides, it is well-known that some youngsters are involved in sports for fun, enjoyment, skill development and learning new skills (Gardner et al., 2017; Dwyer, 1992; Gould, Feltz \& Weiss, 1985). Likewise, Yan \& Penny (2004:978) realised studies with American and Chinese youth in order to analyse cultural influence on participation motivations for sports; thereupon, American youth do sports in order to compete and develop skills, while Chinese get involved for socialising and health. Besides, upon an analysis about participation in combat sports, Özbek \& Şanlı (2011:203) studied on karate players from universities and concluded that youngsters choose karate under the influence of family and friends, as well as for pleasure of winning and better physical appearance. There are many features which affect the motivational characteristics of athletes. Many researches were conducted in different countries with different samples to examine sport participation motivation of athletes (e.g. Gülbahçe et al., 2018; Mishra and Acharya, 2017; Gjesdal, 2017; Ekinci et al., 2017; Shannon, 2016).

\section{AIM of the STUDY}

The current studies in relevant literature put forth the necessity of new studies about motivation for participation in sports in various 


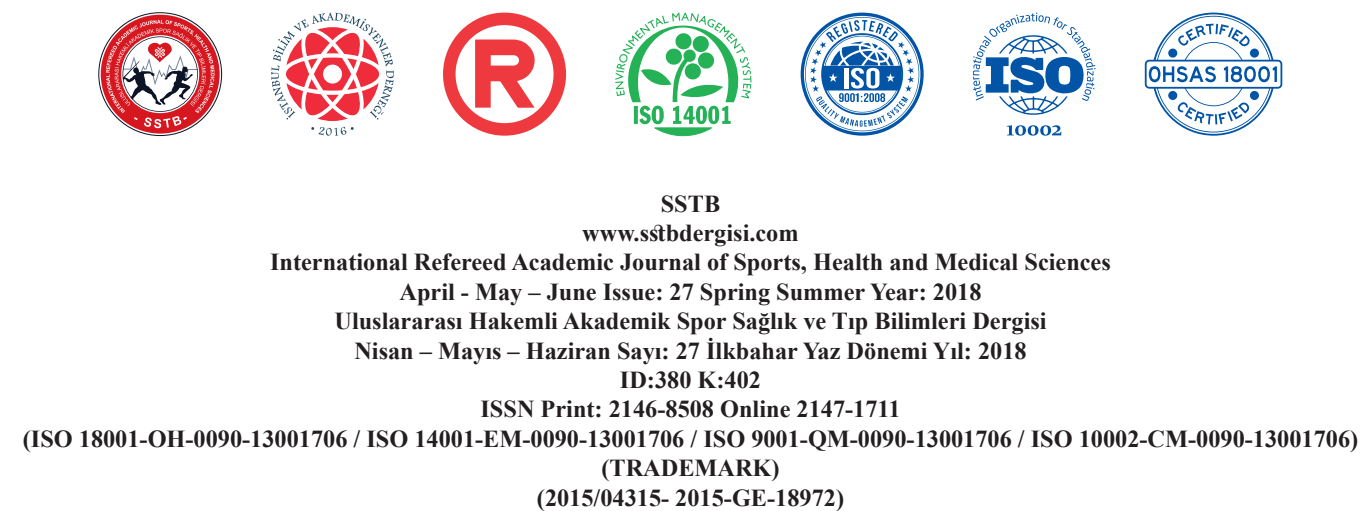

(2015/04315- 2015-GE-18972)

environments and cultures (Benar \& Longhmani, 2014). Therefore, although there have been some research in sport participation motivation of athletes, more research is needed in athletes with different characteristics. In this context, the objective of this study is to determine reasons behind participation of 12 to 16 year-old licensed athletes in combat sports depending on the kind of sport and gender.

\section{RESEARCH METHOD}

\section{Participants}

A total of 604 athletes, namely, 409 males (67.7\%) and 195 females (32.3\%) participated in the survey. In the group, 209 do taekwondo (34.6\%), 65 athletes are involved in kickboxing (10.8\%), 162 do karate (26.8\%), 90 are engaged in judo (14.9\%), while there are 50 wrestlers $(8.3 \%)$ and 28 boxers $(4.6 \%)$. The age of athletes vary between 12 and 16 (their average years in sports are found 3.49 \pm 2.30 years). There are less female athletes in the above mentioned sports therefore the number of males and females are representative of the universe.

\section{Measures}

Sport Participation Motivation Questionnaire

"Sport Participation Motivation Questionnaire" is used for determining the related motivation of workgroup. Hereby scale, devel- oped by Gill, Gross and Huddleston (1983), consists of 30 articles and 8 sub-dimensions so as to determine why athletes participate in sports. These sub-dimensions are named as achievement/status, fitness/energy release, team spirit, friendship, fun, competition, skill development and activity/being active. Athletes evaluate each item over a triple scale, including "Very important (1)," "Somewhat important (2)," and "Not important (3)." During the phase of data entry to computer, hereby study employed a recoding process in dataset so that higher scores signify higher motivation. Accordingly, the data are calculated as "Very important (3)," "Somewhat Important (2)," and "Not important (1)." Consequently, the higher the score in a given sub-dimension reflects the importance of the latter. The scale was adapted to Turkish by Çelebi (1993). Then, Oyar et al (2001) conducted a study of validity and reliability on 9 to 17 year-old Turkish students.

\section{Procedure}

Data collection process took place before or after training sessions of athletes. Permissions were taken from the sports coaches before the data collection. Data collection was conducted by the researchers who are experienced in sport psychology research and sport psychology consultation. Athletes were asked to participate in the survey, once the objective of research was provided. All the athletes 
International Refereed Academic Journal of Sports, Health and Medical Sciences April - May - June Issue: 27 Spring Summer Year: 2018

Uluslararası Hakemli Akademik Spor Sağlık ve Tıp Bilimleri Dergisi

Nisan - Mayıs - Haziran Sayı: 27 İlkbahar Yaz Dönemi Yıl: 2018 ID:380 K:402

ISSN Print: 2146-8508 Online 2147-1711

(ISO 18001-OH-0090-13001706 / ISO 14001-EM-0090-13001706 / ISO 9001-QM-0090-13001706 / ISO 10002-CM-0090-13001706) (TRADEMARK)

(2015/04315- 2015-GE-18972)

were informed that the obtained data will exclusively be used for research purposes.

\section{ANALYSIS}

Once the data were transferred to the software SPSS 17, necessary checks were made for detecting any erroneous entries, and the mistakes were duly corrected. During the data assessment, their percentage frequency, arithmetic mean and standard deviations were calculated. Multivariate analysis of variance
(MANOVA) was used in order to determine any difference in motivation for participation depending on sport branches. Turkey test was employed as post hoc analysis so as to determine between which sport branches there is a significant difference, regarding such differences in motivation of participation. Throughout calculation, significance level was set as 0.05 .

\section{RESULTS}

Table 1. Descriptive Statistics About Scores in Motivation of Sport Participation Among Female and Male Combat Athletes

\begin{tabular}{lllll} 
& Gender & N & $\bar{X}$ & Ss \\
\hline \multirow{2}{*}{ Achievement/Status } & Male & 409 & 2.74 & 0.30 \\
\cline { 2 - 5 } & Female & 195 & 2.76 & 0.30 \\
\hline Team membership/Spirit & Male & 409 & 2.74 & 0.35 \\
\cline { 2 - 5 } & Female & 195 & 2.79 & 0.33 \\
\hline Fitness/ Energy release & Male & 409 & 2.72 & 0.31 \\
\hline Fun & Female & 195 & 2.71 & 0.31 \\
\hline Friendship & Male & 409 & 2.67 & 0.35 \\
\cline { 2 - 5 } & Female & 195 & 2.67 & 0.38 \\
\hline Competition & Male & 409 & 2.68 & 0.39 \\
\cline { 2 - 5 } & Female & 195 & 2.67 & 0.43 \\
\hline Action/ Being active & Male & 409 & 2.77 & 0.34 \\
\cline { 2 - 5 } & Female & 195 & 2.74 & 0.37 \\
\hline Skill development & Male & 409 & 2.82 & 0.35 \\
\cline { 2 - 5 } & Female & 195 & 2.84 & 0.35 \\
\hline
\end{tabular}


International Refereed Academic Journal of Sports, Health and Medical Sciences April - May - June Issue: 27 Spring Summer Year: 2018

Uluslararası Hakemli Akademik Spor Sağlık ve Tıp Bilimleri Dergisi

Nisan - Mayıs - Haziran Sayı: 27 İlkbahar Yaz Dönemi Yıl: 2018 ID:380 K:402

ISSN Print: 2146-8508 Online 2147-1711

(ISO 18001-OH-0090-13001706 / ISO 14001-EM-0090-13001706 / ISO 9001-QM-0090-13001706 / ISO 10002-CM-0090-13001706) (TRADEMARK)

(2015/04315- 2015-GE-18972)

As shown in table 1, upon an analysis on motivation for sports participation among combat athletes as per gender, the motivation types for male athletes are listed, from the most to least important, as follows: skill development, action/ being active, competition, team spirit, achievement/ status, fitness/ energy release, friendship and fun. As for females, the motivations according to importance level are as below: action/ being active, skill development, team spirit, achievement status, fitness/ energy release, fun and friendship.

Table 2. Descriptive Statistics About Scores in Motivation of Sports Participation Among Combat Athletes as Per Branch

\begin{tabular}{|c|c|c|c|c|c|c|c|c|c|}
\hline & Sub-Dimensions & $n$ & $\bar{X}$ & Ss & & Sub-Dimensions & $n$ & $\bar{X}$ & Ss \\
\hline \multirow{8}{*}{ 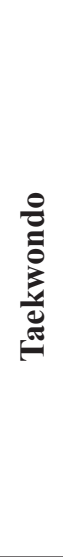 } & Achievement/Status & \multirow{8}{*}{209} & 2.74 & 0.29 & \multirow{8}{*}{$\stackrel{\circ}{\stackrel{0}{g}}$} & Achievement/Status & \multirow{8}{*}{90} & 2.73 & 0.34 \\
\hline & $\begin{array}{l}\text { Team membership/ } \\
\text { Spirit }\end{array}$ & & 2.63 & 0.39 & & Team membership/Spirit & & 2.78 & 0.31 \\
\hline & Fitness/ Energy release & & 2.66 & 0.37 & & Fitness/ Energy release & & 2.74 & 0.28 \\
\hline & Fun & & 2.60 & 0.41 & & Fun & & 2.73 & 0.31 \\
\hline & Friendship & & 2.71 & 0.43 & & Friendship & & 2.65 & 0.41 \\
\hline & Competition & & 2.78 & 0.33 & & Competition & & 2.76 & 0.37 \\
\hline & Action/ Being-active & & 2.83 & 0.36 & & Action/ Being-active & & 2.82 & 0.39 \\
\hline & Skill development & & 2.87 & 0.28 & & Skill development & & 2.82 & 0.26 \\
\hline \multirow{8}{*}{ 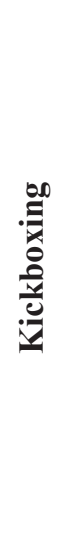 } & Achievement/Status & \multirow{8}{*}{65} & 2.78 & 0.28 & \multirow{8}{*}{ 象 } & Achievement/Status & \multirow{8}{*}{50} & 2.71 & 0.32 \\
\hline & $\begin{array}{l}\text { Team membership/ } \\
\text { Spirit }\end{array}$ & & 2.84 & 0.38 & & Team membership/Spirit & & 2.82 & 0.27 \\
\hline & Fitness/ Energy release & & 2.83 & 0.20 & & Fitness/ Energy release & & 2.69 & 0.31 \\
\hline & Fun & & 2.79 & 0.34 & & Fun & & 2.62 & 0.39 \\
\hline & Friendship & & 2.76 & 0.40 & & Friendship & & 2.53 & 0.45 \\
\hline & Competition & & 2.90 & 0.22 & & Competition & & 2.78 & 0.37 \\
\hline & Action/ Being-active & & 2.88 & 0.25 & & Action/ Being-active & & 2.78 & 0.35 \\
\hline & Skill development & & 2.92 & 0.16 & & Skill development & & 2.85 & 0.31 \\
\hline
\end{tabular}


SSTB

www.sstbdergisi.com

International Refereed Academic Journal of Sports, Health and Medical Sciences April - May - June Issue: 27 Spring Summer Year: 2018

Uluslararası Hakemli Akademik Spor Sağlık ve Tıp Bilimleri Dergisi

Nisan - Mayıs - Haziran Sayı: 27 İlkbahar Yaz Dönemi Yıl: 2018 ID:380 K:402

ISSN Print: 2146-8508 Online 2147-1711

(ISO 18001-OH-0090-13001706 / ISO 14001-EM-0090-13001706 / ISO 9001-QM-0090-13001706 / ISO 10002-CM-0090-13001706) (TRADEMARK)

(2015/04315- 2015-GE-18972)

\begin{tabular}{|c|c|c|c|c|c|c|c|c|c|}
\hline \multirow{8}{*}{ 节 } & Achievement/Status & \multirow{8}{*}{162} & 2.74 & 0.30 & \multirow{8}{*}{ • } & Achievement/Status & \multirow{8}{*}{28} & 2.78 & 0.23 \\
\hline & $\begin{array}{l}\text { Team membership/ } \\
\text { Spirit }\end{array}$ & & 2.86 & 0.27 & & Team membership/Spirit & & 2.78 & 0.23 \\
\hline & Fitness/ Energy release & & 2.76 & 0.28 & & Fitness/ Energy release & & 2.71 & 0.26 \\
\hline & Fun & & 2.70 & 0.32 & & Fun & & 2.69 & 0.32 \\
\hline & Friendship & & 2.67 & 0.34 & & Friendship & & 2.57 & 0.42 \\
\hline & Competition & & 2.69 & 0.38 & & Competition & & 2.70 & 0.28 \\
\hline & Action/ Being-active & & 2.83 & 0.35 & & Action/ Being-active & & 2.84 & 0.27 \\
\hline & Skill development & & 2.86 & 0.21 & & Skill development & & 2.88 & 0.21 \\
\hline
\end{tabular}

As shown in table 2, according to average scores of motivation for sports participation as per branches, the most and least important reasons for participation in taekwondo are skill development and fun, respectively. In kickboxing, the most important motivation is skill development while the least important is friendship; in karate, team spirit and skill development are the most important (0.21) whereas friendship is the least. Judokas consider action/being vital and friendship insignificant; wrestlers see skill development as the most important and friendship as the least, while among boxers, skill development is of utmost importance, where friendship does not matter.

Table 3. Results of Multivariate Analysis of Variance (MANOVA) on Motivation Scores of Sports Participation as Per Branch

\begin{tabular}{lllllll} 
Impact & Wilks' $\lambda$ & $F$ & Hypothesis SD & Error SD & Sig. & Partial $\eta^{2}$ \\
\hline Intersection & .008 & 9117.071 & 8.000 & 591.000 & .000 & .992 \\
\hline Sport Branch & .798 & 3.425 & 40.000 & 2578.904 & .000 & .044
\end{tabular}

According to table 3, pursuant to results of MANOVA test, there is a significant difference between the scores of motivation for sports participation as per branch. F (40. $2578.00)=3.425, \mathrm{p}=.000$; Wilks' $\lambda=.798$;
Partial $\eta^{2}=.044$. ANOVA analysis was applied in order to determine which dependent variable/variables lead to the mentioned difference. 
SSTB

www.sstbdergisi.com

International Refereed Academic Journal of Sports, Health and Medical Sciences April - May - June Issue: 27 Spring Summer Year: 2018

Uluslararası Hakemli Akademik Spor Sağlık ve Tıp Bilimleri Dergis

Nisan - Mayıs - Haziran Sayı: 27 İlkbahar Yaz Dönemi Yıı: 2018 ID:380 K:402

ISSN Print: 2146-8508 Online 2147-1711

(ISO 18001-OH-0090-13001706 / ISO 14001-EM-0090-13001706 / ISO 9001-QM-0090-13001706 / ISO 10002-CM-0090-13001706) (TRADEMARK)

(2015/04315- 2015-GE-18972)

Table 4. Results of ANOVA Test On Motivation of Sport Participation as Per Branch

\begin{tabular}{|c|c|c|c|c|c|c|c|}
\hline Source & Dependent variable & $\begin{array}{l}\text { Sum of } \\
\text { squares }\end{array}$ & $\begin{array}{l}\text { Degree of } \\
\text { freedom }\end{array}$ & $\begin{array}{l}\text { Mean of } \\
\text { squares }\end{array}$ & $\mathrm{F}$ & $\mathrm{P}$ & $\begin{array}{l}\text { Partial } \\
\eta^{2}\end{array}$ \\
\hline \multirow{8}{*}{$\begin{array}{l}\text { Sports } \\
\text { branch }\end{array}$} & Achievement/Status & .204 & 5 & .041 & .448 & .815 & .004 \\
\hline & Team membership/Spirit & 5.961 & 5 & 1.192 & 10.742 & .000 & .082 \\
\hline & Fitness/Energy release & 1.966 & 5 & .393 & 4.204 & .001 & .034 \\
\hline & Fun & 2.463 & 5 & .493 & 3.855 & .002 & .031 \\
\hline & Friendship & 2.082 & 5 & .416 & 2.567 & .026 & .021 \\
\hline & Competition & 2.363 & 5 & .473 & 4.040 & .001 & .033 \\
\hline & Action/Being active & .338 & 5 & .068 & .561 & .730 & .005 \\
\hline & Skill development & .465 & 5 & .093 & 1.492 & .191 & .012 \\
\hline \multirow[t]{8}{*}{ Error } & Achievement/Status & 54.425 & 598 & .091 & & & \\
\hline & Team membership/Spirit & 66.372 & 598 & .111 & & & \\
\hline & Fitness/Energy release & 55.931 & 598 & .094 & & & \\
\hline & Fun & 76.409 & 598 & .128 & & & \\
\hline & Friendship & 96.993 & 598 & .162 & & & \\
\hline & Competition & 69.939 & 598 & .117 & & & \\
\hline & Action/Being active & 72.097 & 598 & .121 & & & \\
\hline & Skill development & 37.272 & 598 & .062 & & & \\
\hline \multirow[t]{8}{*}{ Total } & Achievement/Status & 4602.600 & 604 & & & & \\
\hline & Team membership/Spirit & 4667.625 & 604 & & & & \\
\hline & Fitness/Energy release & 4523.920 & 604 & & & & \\
\hline & Fun & 4397.125 & 604 & & & & \\
\hline & Friendship & 4419.111 & 604 & & & & \\
\hline & Competition & 4686.000 & 604 & & & & \\
\hline & Action/Being active & 4908.000 & 604 & & & & \\
\hline & Skill development & 4991.438 & 604 & & & & \\
\hline
\end{tabular}

As shown in table 4 , once the analysis results are separately evaluated for each dependent variable, significant differences are deter- mined as below: For team spirit, $\mathrm{F}(5,598)=$ 10.742. $\mathrm{p}=.000$. Partial $\eta 2=.082$; for fitness/energy release, $\mathrm{F}(5,598)=4.204, \mathrm{p}=$ 


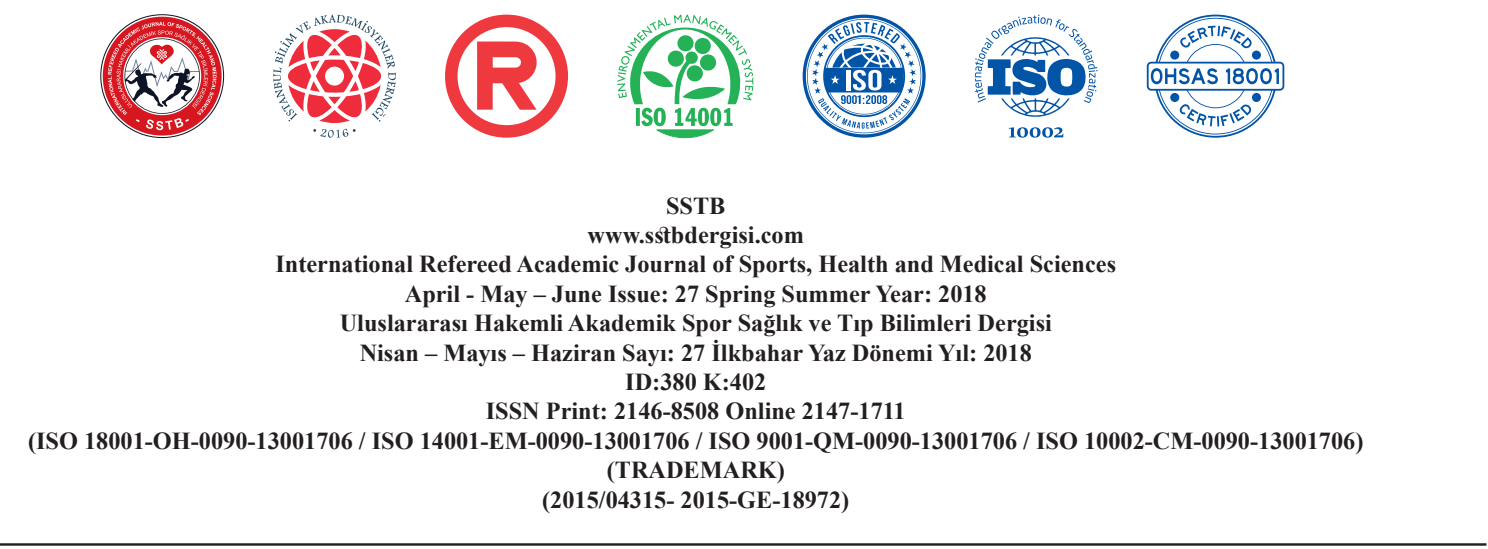

.001 , Partial $\eta 2=.034$; for fun, $\mathrm{F}(5,598)=$ $3.855, \mathrm{p}=.002$. Partial $\eta 2=.031$; for friendship, $\mathrm{F}(5,598)=2.567, \mathrm{p}=.026$, Partial $\eta 2=$ .021 ; and for competition, $\mathrm{F}(5,598)=4.040$. $\mathrm{p}=.001$, Partial $\eta 2=.033$.

In the wake of Turkey post hoc analysis to determine between which branches significant difference occurs, team spirit scores are significantly lower for taekwondo $(2.74 \pm 0.29)$, kickboxing (2.84 \pm 0.38$)$, karate $(2.86 \pm 0.27)$, judo (2.78 \pm 0.31$)$ and wrestling $(2.82 \pm 0.27)$.

As for fitness/energy release aspect, the average score for taekwondo is found (2.66 \pm 0.37$)$, and it is significantly lower than those of kickboxing (2.83 \pm 0.20$)$ and karate $(2.76 \pm 0.28)$.

The significant difference with respect to fun arises from the difference between average scores in taekwondo (2.60 \pm 0.41$)$ and kickboxing (2.79 \pm 0.34$)$. An analysis on friendship aspect shows that the difference is due to kickboxing $(2.76 \pm 0.40)$ and wrestling $(2.53 \pm 0.45)$. The significant difference regarding competition aspect originates from the difference of average scores in karate (2.69 \pm 0.38$)$ and kickboxing $(2.76 \pm 0.40)$.

\section{DISCUSSION}

It is important to determine participation motivations among youth for sports so as to take measures to prevent them from alienating from sports and physical activity. The number of relevant studies gradually has recently increased (e.g. Sindik et al., 2013:14-31; Cope et al., 2013:56-75; Gülbahçe et al., 2018: 7987; Mishra and Acharya, 2017: 79-85). Hereby this research aims at determining reasons for participation of 12-16 year-old athletes in sports as per sports branch; and results reveal different participation motives for different sports. According to the findings, the scores in team spirit, fitness/energy release, fun, friendship and competition differ depending on branches of athletes.

The relevant studies put forth the difference in motivation for sports participation depending on certain features of athletes. For example, Altıntaş and Koruç (2014) conducted a research in order to analyse young athletes' motivation as per gender and sport. Pursuant to results of their study, no significant difference of participation motivation is in question with respect to gender. Nonetheless, athletes in team sports have significantly higher scores in sub-dimensions of team spirit and friendship, compared to those in individual sports (Altıntaş \& Koruç 2014:65). Another study examines participation motivation for sports among 15-18 year-old high school student in terms of diverse variables. Thereupon, the sub-dimension "competition" is more important among footballers compared to those in "other branches" group. Moreover, the subdimension of friendship is more important 


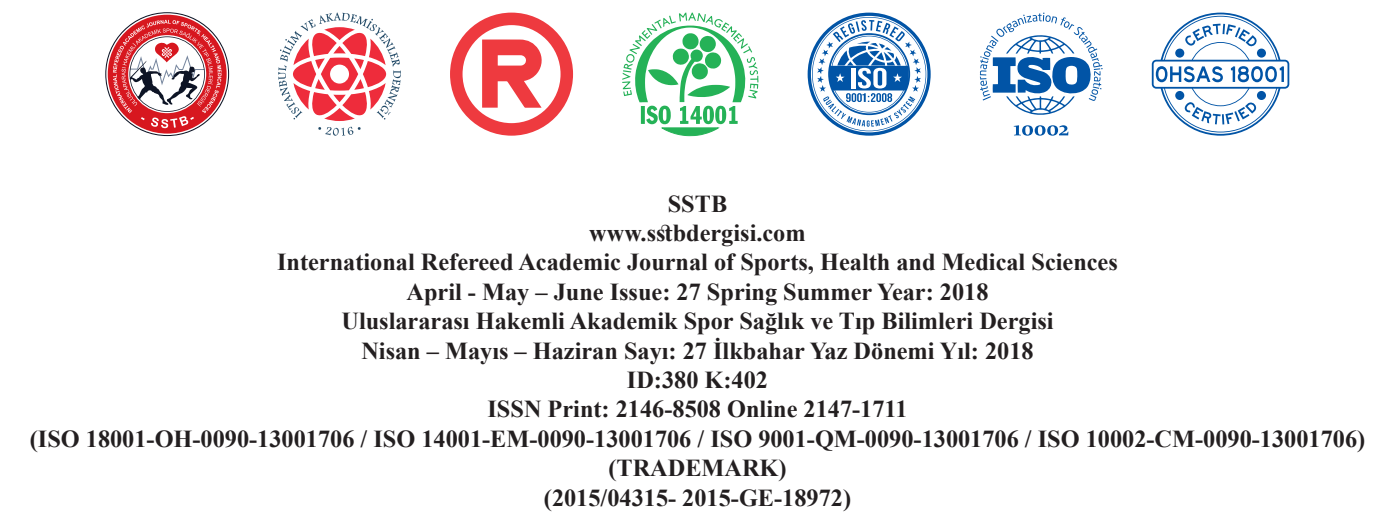

for volleyball and football players than it is for basketball players (Şirin et al, 2008:104). Korur et al (2013:233) analysed the participation motivation of youth for sports with regard to certain variables, and concluded that the motivation differs depending on gender, age, sports branch and geographical region. Pursuant to the study by Erdoğdu et al (2014: 262), the dimensions of achievement/ status, fun and friendship display dramatic changes as per sports branch. There are some differences among athletes therefore sport participation motivation is examined in different cultures with different samples (e.g. Gülbahçe et al., 2018; Mishra and Acharya, 2017; Gjesdal, 2017; Shannon, 2016).

Environmental factors should comply with the motivation among children for participation and continuity in sports, for that they are orientated to sports and other physical activities at an early age (Cope et al, 2013:57). For this purpose, relevant literature comprises various recommendations about behaviours and practices by trainers so as to ensure active participation of children in sports (Cope et al, 2013:67). For example, Pelletier et al (2001) carried out a study with swimmers at an average age of 15.6, and found out that an environment which supports autonomy of athletes may have a positive impact on the quality of motivation compared to a non-autonomous and more controlling envi- ronment (Pelletier et al, 2001:279). Another research to determine participation motivation among young Americans, Australians and New Zealanders yielded similar results regarding motivation in the mentioned countries. The analyses as per gender indicate that competition is a greater motivation among boys, while girls participate in sport more for social reasons and fitness (Weinberg et al, 2000:342). According to a study on adults between 20 to 30 year-olds, the participation motivations pursuant to importance level are determined as follows: social energy, fitness, energy release, intrinsic motivation, teamwork, fun, extrinsic motivation and competition. Besides, differences were observed between women and men regarding mentioned motivations (Afsanepurak, et al., 2012:793). Again, the intrinsic motivations for physical training among students who join afterschool sport activities are found much higher than those who do not (Koka \& Hein, 2003:86). An article derives scientific studies with qualitative research methods; and it examines individuals who lived in England between 1990 and 2004 regarding the experience of participants in sports and physical activities, as well as their reasons for participating in sports/physical activities or not; accordingly, the individuals join sports and physical activities so as to initiate and maintain fun and social relationships (Allender et al., 2006:829). Pursuant to another survey on participation 


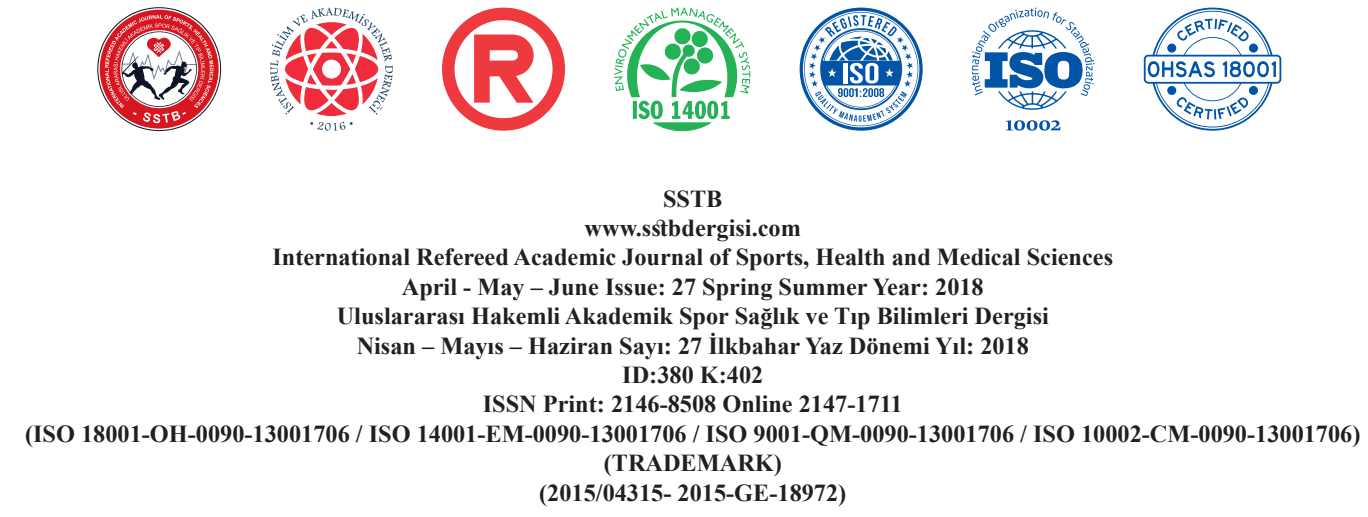

reasons of students in sports and exercises, intrinsic motives came to the forefront such as fun and challenge. As for participation in exercises, the extrinsic reasons such as physical appearance, overweight and overcoming stress stand out among individuals (Kilpatrick et al., 2006:87). According to another study in England, affiliation, fitness, skill development and friendship are the four fundamental participation motivations for martial artists (Jones et al., 2006:30).

\section{CONCLUSION}

The results of hereby study manifests different participation motivations among athletes in combat sports depending on branch. In other words, there is a prominent motivation in each sport branch. Such difference may be due to different individual features and requirements. Besides, the unique structure and character of each sport should not be overlooked. Once young athletes find the sports environment compatible with their participation reasons, they will like practising sports more and will continue training. This could also prevent dropouts from sports. These findings provide unique information for sports coaches, sport psychologists and the parents. Each athlete's motivational features should be known. This information then can be used to increase persistence of the athletes and to create a better sports environment and experience.

\section{REFERENCES}

AFSANEPURAK, S.A., HOSSINI, R.N.S., SEYFARI, M.K., FATHI, H., (2012). Analysis of Motivation for Participation in Sport for All. International Research Journal of Applied and Basic Sciences, 3(4): 790-795

AFZAL, H., IMRAN, A., ASLAM, K.M., KASHIF, H., (2010). A Study of University Students' Motivation and Its Relationship with Their Academic Performance. International Journal of Business \& Management, 5(4): 80-88

ALLENDER, S., COWBURN, G., FOSTER, C., (2006). Understanding participation in sport and physical activity among children and adults: a review of qualitative studies. Health Education Research, 21(6): 826-835

ALTINTAŞ, A., KORUÇ, P.B., (2014). Determining Participation Motivation of Young Athletes With Regard to Gender and Sport Type. International Journal of Science Culture and Sport Special Issue. (1): 61-67

ARSLAN, Y., ALTAY, F., (2009). The examination of sport participation motives of the elemantary school male students in school teams. CBU Journal of Physical 
International Refereed Academic Journal of Sports, Health and Medical Sciences April - May - June Issue: 27 Spring Summer Year: 2018

Uluslararası Hakemli Akademik Spor Sağlık ve Tıp Bilimleri Dergisi

Nisan - Mayıs - Haziran Sayı: 27 İlkbahar Yaz Dönemi Yıl: 2018 ID:380 K:402

ISSN Print: 2146-8508 Online 2147-1711

(ISO 18001-OH-0090-13001706 / ISO 14001-EM-0090-13001706 / ISO 9001-QM-0090-13001706 / ISO 10002-CM-0090-13001706) (TRADEMARK)

(2015/04315- 2015-GE-18972)

Education and Sport Sciences, 4(2): 59-66 [in Turkish]

BENAR, N., LOGHMANI, M., (2014). Factor Analysis of Teenage Athletes' Goal Orientations and Sports Participation Motives in Leisure Time. Ann Appl Sport Sci, 2(1): 69-80

ÇELEBİ, A.M., (1993). Orta Doğu Teknik Üniversitesi fiziksel aktivite kulüplerinde bulunan lider tipleri. Master dissertation, ODTÜ: Ankara

CLEWS, G.J., GROSS, J.B., (1995). Individual and Social Motivation in Australian Sport. In T.Morris and J. Summers (Eds.) Sport Psychology: Theory, Application, and Issues. John Wiley and Sons

COPE, E.J., BAILEY, R., PEARCE, G., (2013). Why do children take part in, and remain involved in sport? A literature review and discussion of implications for sports coaches. International Journal of Coaching Science, 7(1): 56-75

DECI, E.L., CASCIO, W.F., KRUSELL. J., (1975). Cognitive evaluation theory and some comments on the Calder and Staw critique. J Pers Soc Psychol, (31): 81-85

DECI, E.L., RYAN, R.M., (1985). Intrinsic Motivation and Self-determination in $\mathrm{Hu}-$ man Behavior, Plenum Press, New York
DWYER, J.M., (1992). Internal Structure of Participation Motivation Questionnaire Completed by Undergraduates. Psychol Rep, (70): 283-290

EKINCI, N.E., BISGIN, H., USTUN, U.D., (2017). Expressed motives of amateur karate and taekwondo athletes for sport participation. Turkish Journal of Sport and Exercise, 19(3): 360-362

ERDOĞDU, M., ŞİRIN, E.F., INCE, A., ÖÇALAN, M., (2014). Farkl1 branşlarda okul takımlarında yer alan ortaöğretim öğrencilerin spora katılım motivasyonlarının incelenmesi. Niğde Üniversitesi Beden Egitimi ve Spor Bilimleri Dergisi, 8(1):157-166

FREDERICK-RECASCINO, C.M., SCHUSTER-SMITH, H., (2003). Competition and intrinsic motivation in physical activity: A comparison of two groups. J Sport Behav, 26(3): 240-254

GARDNER, L., MAGEE, C. VELLA, S., (2017). Enjoyment and behavioral intention predict organized youth sport participation and dropout. Journal of Physical Activity and Health, 14(11): 861-865

GILL, D.L., GROSS, J.B., HUDDLESTON, S., (1983). Participation motivation in youth sports. Int J Sport Psychol, (14): $1-14$ 
International Refereed Academic Journal of Sports, Health and Medical Sciences April - May - June Issue: 27 Spring Summer Year: 2018

Uluslararası Hakemli Akademik Spor Sağlık ve Tıp Bilimleri Dergisi

Nisan - Mayıs - Haziran Sayı: 27 İlkbahar Yaz Dönemi Yıl: 2018 ID:380 K:402

ISSN Print: 2146-8508 Online 2147-1711

(ISO 18001-OH-0090-13001706 / ISO 14001-EM-0090-13001706 / ISO 9001-QM-0090-13001706 / ISO 10002-CM-0090-13001706) (TRADEMARK)

GJESDAL, S., APPLETON, P.R., OMMUNDSEN, Y., (2017). Both the "what" and "why" of youth sports participation matter; a conditional process analysis. Frontiers in psychology, (8): 659

GOULD, D., FELTZ, D., WEISS, M., (1985).

Motives for Participation in Competitive Youth Swimming. Int J Sport Psychol, (16): $126-140$

GÜLBAHÇE, Ö., TOZOĞLU, E., BAYRAKTAR, G., DURSUN, M., GÜLBAHÇE, $\boldsymbol{A}$., (2018). THE ANALYSIS OF RELATION BETWEEN DIFFERENT VARIABLES AND UNIVERSITY STUDENTS'MOTIVES FOR PARTICIPATION IN SPORTS. European Journal of Physical Education and Sport Science. 4(2):79-87

INGLEDEW, D.K., MARKLAND, D., MEDLEY, A.R., (1998). Exercise motives and stages of change. Health Psychol, 3(4): 477-489

JONES, G.W., MACKAY, K.S., PETERS, D.M., (2006). Participation Motivation In Martial Artists In The West Midlands Region of England. J Sports Sci Med CCSII, 28-34

KILPATRICK, M., HEBERT, E., BARTHOLOMEW, J., (2005). College students' motivation for physical activity: differ- entiating men's and women's motives for sport participation and exercise. J Am Coll Health, 54(2): 87-94

KOIVULA, N., (1999). Sport participation: Differences in motivation and actual participation due to gender typing J Sport Behav, (22): 360-380

KOKA, A., HEIN, V., (2003). The impact of sports participation after school on intrinsic motivation and perceived learning environment in secondary school physical education. Kinesiology, 35(1): 86-93

KOLT, G., KIRBY, R., BAR-ELI M., BLUMENSTEIN, B., CHADHA, N.K., LIU, J., KERR, G., (1999). A Crosscultural Investigation of Reasons for Participation in Gymnastics. Int J Sport Psychol, (30): 381-398

KORUR, E.N., KARA, F.M., ÖNCÜ, E., (2013). Gençlerin Spora Katılım Güdülerinin İncelenmesi. II. Recreation Research Congress, Aydın, Turkey, 233-238

MISHRA, M., ACHARYA, A., (2017). Relationships between motivation type and sport participation among Indian students. International Journal of Physical Education, Sports and Health, 4(3): 5-7

MORENO, J.A., GONZÁLEZ-CUTRE, D. MARTÍN-ALBO, J., CERVELLÓ, E., (2010). Motivation and performance in 
International Refereed Academic Journal of Sports, Health and Medical Sciences April - May - June Issue: 27 Spring Summer Year: 2018

Uluslararası Hakemli Akademik Spor Sağlık ve Tıp Bilimleri Dergisi

Nisan - Mayıs - Haziran Sayı: 27 İlkbahar Yaz Dönemi Yıl: 2018 ID:380 K:402

ISSN Print: 2146-8508 Online 2147-1711

(ISO 18001-OH-0090-13001706 / ISO 14001-EM-0090-13001706 / ISO 9001-QM-0090-13001706 / ISO 10002-CM-0090-13001706) (TRADEMARK)

physical education: An experimental test.

J Sports Sci Med, 9(1): 79-85

MORRIS, T., CLAYTON, H., POWER, H., JIN-SONG, H., (1995). Gender and motives for participation in sport and exercise. Proceedings of the FEPSAC IX European Congress of Sport Psychology, 364-373

OYAR, Z.B., AŞÇI, F.H., ÇELEBI M., MÜLAZIMOĞLU, Ö., (2001). Validity and reliability of "participation motivation questionnaire". Hacettepe Journal of Sports Science, 12 (2): 21-32

ÖZBEK, O., ŞANLI, E., (2011). Causes of propensity for elite athletes in universities to take up karate and their expectations. Nigde University Journal of Physical Education and Sport Sciences, 5(3): 203-214

PEHLIVAN, Z., (2010). The reasons why students, Who involve in interschool sports competitons, continue sports participation and drop out of sports. 11.th International Sport Science Congres Abstract Book, 163-166

PELLETIER, L.G., FORTIER, M.S., VALLERAND, R.J., BRIERE, N.M., (2001). Associations among perceived autonomy supportive, forms of self-regulation, and persistence: a prospective study. Motiv Emot, 25(4): 279-306

RINTAUGU, E.G., NTEERE, J.S., (2011). Research Article Motivational Orientations In Sport: A Study Of College Athletes In Kenya. International Journal of Current Research, 3(8): 168-171

RYAN, R.M., DECI, E.L., (2000). Intrinsic and extrinsic motivations: Classic definitions and new directions. Contemp Educ Psychol, 25(1): 54-67

SHANNON, C.S., (2016). Exploring Factors Influencing Girls' Continued Participation in Competitive Dance. Journal of Leisure Research, 48(4): 284-306

SINDIK, J., FURJAN-MANDIĆ, G., SCHIEFLER, B., KONDRIČ, M., (2013). Difference in the structure of motivation for participation in sport activities among sport students in three countries. Kinesiologia Slovenica. 19(1): 14-31

ŞİRIN, E.F., ÇA ĞLAYAN, H.S., ÇETİN, M.Ç., INCE, A., (2008). Determination of factors affecting sports participation motivation of high school students who make sports. Nigde University Journal of Physical Education and Sport Sciences, 2(2): $98-110$ 
SSTB

www.sstbdergisi.com

International Refereed Academic Journal of Sports, Health and Medical Sciences April - May - June Issue: 27 Spring Summer Year: 2018

Uluslararası Hakemli Akademik Spor Sağlık ve Tıp Bilimleri Dergisi

Nisan - Mayıs - Haziran Sayı: 27 İlkbahar Yaz Dönemi Yıl: 2018 ID:380 K:402

ISSN Print: 2146-8508 Online 2147-1711

(ISO 18001-OH-0090-13001706 / ISO 14001-EM-0090-13001706 / ISO 9001-QM-0090-13001706 / ISO 10002-CM-0090-13001706) (TRADEMARK)

(2015/04315- 2015-GE-18972)

VISEK, A.J., ACHRATI, S.M., MANNIX, H.M., MCDONNELL, K., HARRIS, B.S., DIPIETRO, L., (2015). The fun integration theory: toward sustaining children and adolescents sport participation. Journal of Physical Activity and Health, 12(3): 424-433

WEINBERG, R., TENENBAUM, G., MCKENZIE, A., JACKSON, S., ANSHEL, M., GROVE, R., FOGARTY G., (2000). Motivation for youth participation in sport and physical activity: relationships to culture, self-reported activity levels, and gender. Int J Sport Psychol, (31): 321-346

WEISS, M.R., CHAUMETON, N., (1992). Motivational orientations in sport. In T. Horn. Champaign, IL: Human Kinetics.
(Eds.), Advances in Sport Psychology, 61-101

WHITE, S.A., DUDA J.L., (1994). The relationship of gender, level of sport involvement, and participation motivation to task and ego orientation. Int J Sport Psychol, 25(1): 4-18

YAN, J.H., MCCULLAGH, P., (2004). Cultural influence on youth's motivation of participation in physical activity. J Sport Behav, 27(4): 378-390

Author Notation: This research was presented at the 14th European Congress of Sport Psychologv, 14-19 Julv, Bern. Switzerland. 